\title{
MINING AND TECHNICAL CONDITIONS IN OPEN PIT "KHAN KRUM" GOLD MINE IN SOUTHEASTERN BULGARIA
}

DOI: http://dx.doi.org/10.18509/GBP.2020.15

UDC: 553.411:622.271.33.014(497.2)

\author{
Maya Grigorova \\ Ivaylo Koprev \\ University of Mining and Geology “St. Ivan Rilski”, Bulgaria
}

\begin{abstract}
In terms of Bulgaria's physiographic division, the prospect area is located within the East Rhodopean sub-region, which is part of the East Rhodopean-Strandzha region. The Ada Tepe prospect, which is under consideration, is located approximately $3 \mathrm{~km}$ southwest of the town of Krumovgrad and $1 \mathrm{~km}$ west of the Krumovitsa River. The Krumovgrad district is characterised by a moderate hilly to low-mountainous topography. The "Khan Krum" field includes four sections - Ada Tepe, Kaklitsa, Sarnak and Skalak. On this stage mining works are developed only in the area of Ada Tepe. The ore at Ada Tepe will be open-pit mined. The mining method will be a conventional open cut drill, blast, load and haul operation. Processing of ore to concentrate is done after primary crushing and grinding within the gold-silver concentrate production facility (process plant) with fully enclosed transfer. Flotation using reagents and dewatering produce the end product gold-silver concentrate. All rock material without economic gold and silver values and therefore classified as mining waste, that includes rock materials, waste from enrichment, soil, ores and low grade ores are stored in an Integrated Mining Waste Facility (IMWF) located approximately $200 \mathrm{~m}$ south-southeast of the open pit. The IMWF is designed to store both dewatered process tailings and waste rock from mining.
\end{abstract}

Keywords: mining works, open pit, process plant, gold.

\section{INTRODUCTION}

The present study helps in understanding the mining and technical conditions in the area of open pit "Ada Tepe" gold mine part of the "Khan Krum" gold mine. The region lies is an integral part of the Eastern Rhodopes Massif, which hosts the eastern part of a large metamorphic terrain. The massif is associated with late Cretaceous-Miocene extension, which exposed the underlying lower crust rocks. Basement rocks in the Krumovgrad area consist of Precambrian and Paleozoic metasediments, gneisses, and amphibolites. The basement is unconformable overlain by Paleogene conglomerates, sandstones, siltstones and limestones of the Krumovgrad group that were deposited during rapid uplift of the metamorphic core complex. The "Ada Tepe" deposit is classified as a low sulphidation type epithermal gold-silver deposit and was formed in the Early Oligocene. Gold and silver mineralisation in the research area is mostly identified within the Shavar formation, above shallow fault contacts (listric or detachment) with the underlying metamorphic basement rocks (Kessebir-Kardamos core complex). The sedimentary rocks typically form laterally discontinuous lenses, ranging from breccias to conglomerates to interbedded pebbly sandstones, siltstone, and marl to marl-argillite. 
The dominant structure at the "Ada Tepe" gold mine is a 'detachment' fault that separates the metamorphic basement rocks from the overlying mineralized sedimentary rocks, and forms a $10^{\circ}$ to $15^{\circ}$ north dipping lower structural bounding surface to the deposit [1].

\section{DESCRIPTION OF THE TECHNOLOGICAL CYCLE}

According to the Annual information form [2] the "Ada Tepe" deposit is expected to produce, on average, 85,700 ounces of gold per annum, based on the mineral reserve. In terms of getting the most out of production process key element is preliminary research works and preparation of the ore. The incorporation of any prior information available can significantly improve the quality of the result. Prior information from direct measurements, boreholes or from structural imaging techniques as electrical resistivity tomography (ERT) is significant for quality and precise production process. As a popular geophysical subsurface-imaging technique electrical resistivity tomography is widely applied to mineral prospecting, mining exploration and also environmental investigation. ERT deserves a growingly larger attention since it is a low-cost and high-resolution technique that can rapidly image subsurface. Specific challenges for imaging techniques are the following:

- Main problem is to overcome the ambiguity, i.e. to choose the model that is least in contradiction with knowledge or different kinds of expectations.

- An optimum survey design has to be chosen to maximize the accuracy of the results [3].

In this research electrical resistivity tomography (ERT) is used to detect and characterize layers by exploiting resistivity contrasts between different geological features using electrical current. This information is than used for rocks differentiation on the terrain and to support drilling blasting works helping to set up the blasting energy in the areas with hard rocks. It is very important to estimate blast displacement in order to minimize ore loss and dilution. In this way geophysical study is successfully used for solving specific mining problems providing useful additional information about the rock species in the working horizon. Detailed geophysical study is performed on horizon $445 \mathrm{~m}$ and horizon $440 \mathrm{~m}$. According to the results based on the electrical resistance of different kind of rocks is established that the main rock types are clays, breccia conglomerate, breccia conglomerate with quartz inclusions and metamorphic clasts. This information is claimed by several drillings around the research area.

On the picture below are shown the main rock types in "Ada Tepe" gold mine (Figure 1):

- A-Siltstone;

- B-Clay;

- C-Breccia conglomerate;

- D - Breccia conglomerate with quartz inclusions; 


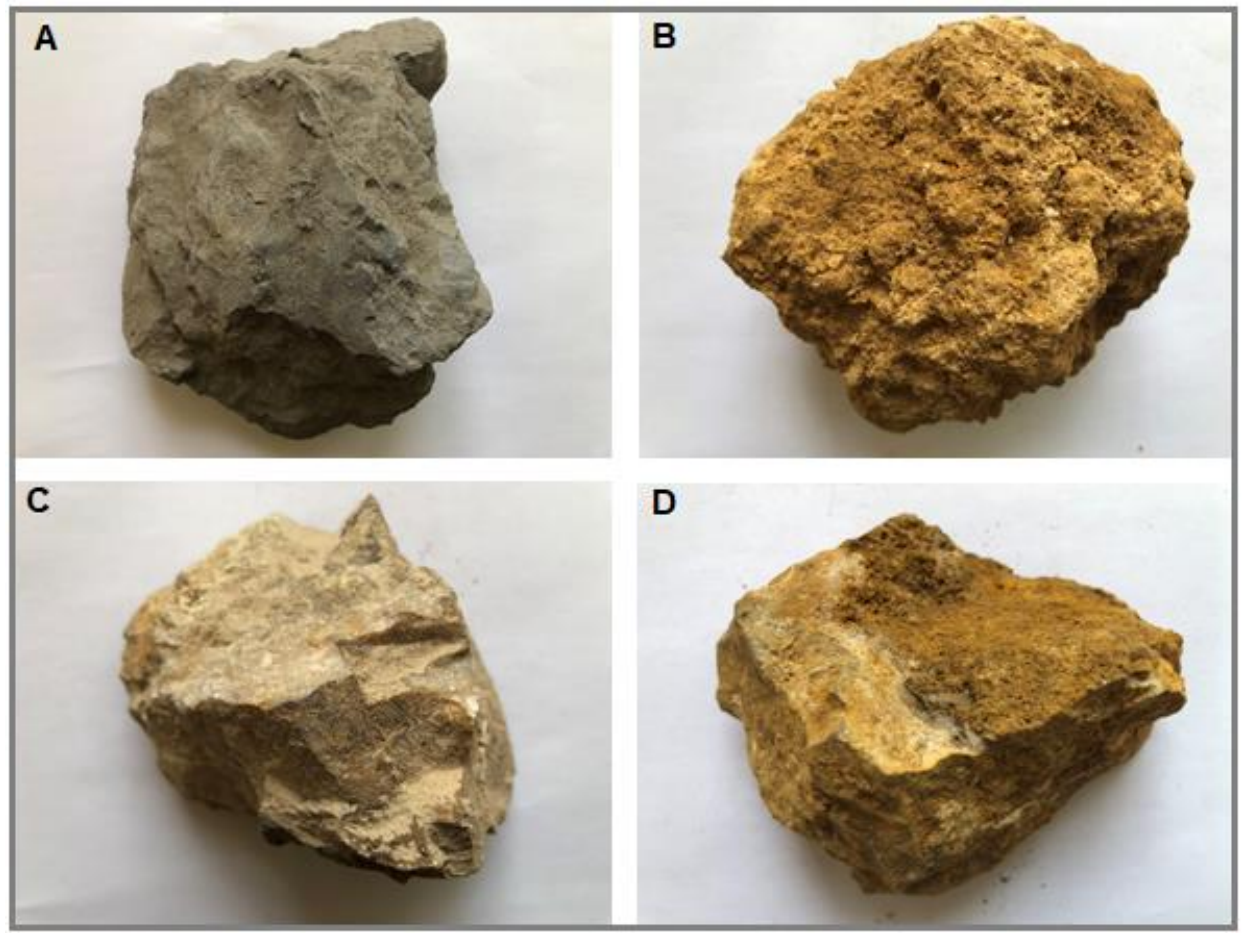

Figure 1. Main rock types in "Ada Tepe" gold mine deposit, A - Siltstone, B - Clay, C - Breccia conglomerate, D - Breccia conglomerate with quartz inclusions

This kind of prior information is significant for following mining works, first because it is crucial for planning blasting energy distribution and second because it makes separation of ore and waste much easier. The operation is planned to utilize conventional mining techniques to separate ore and waste. All ore and waste are mined via conventional, open pit mining methods.

Open-pit method of mining consisting of 4 stages, using drilling and blasting is proposed for the "Ada Tepe" gold mine.

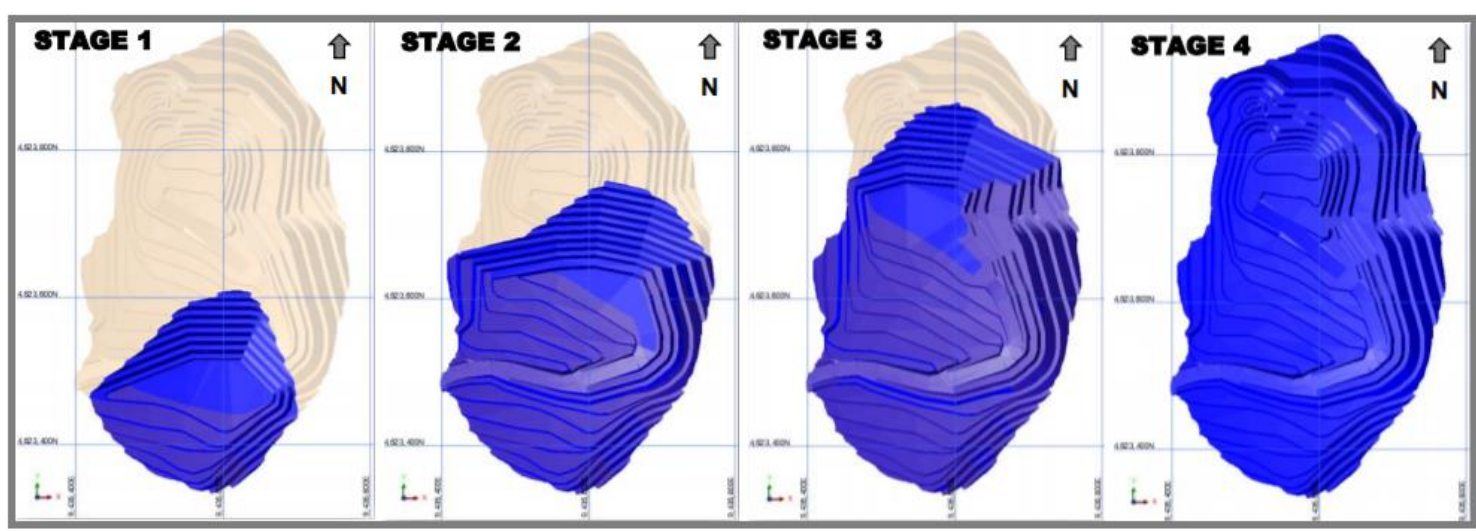

Figure 2. Open-pit stages in "Ada Tepe" gold mine deposit

The pit advances north by mining out each phase progressively from stage 1 through to stage 4 . The pit stages are mined to the final wall on the east side of the pit and a temporary wall to the north is established. Excavating capacity starts from 8,000 t/d in year one and increase to $9,500 \mathrm{t} / \mathrm{d}$ in the last five years due to high stripping in stages 3 and 4 over the life of the mine [4]. 
The mining equipment considered suitable for the mining operation at "Ada Tepe" gold mine includes two $3.7 \mathrm{~m}^{3}$ bucket excavators, and haul trucks with a payload capacity of 40 tonnes (Figure 2).

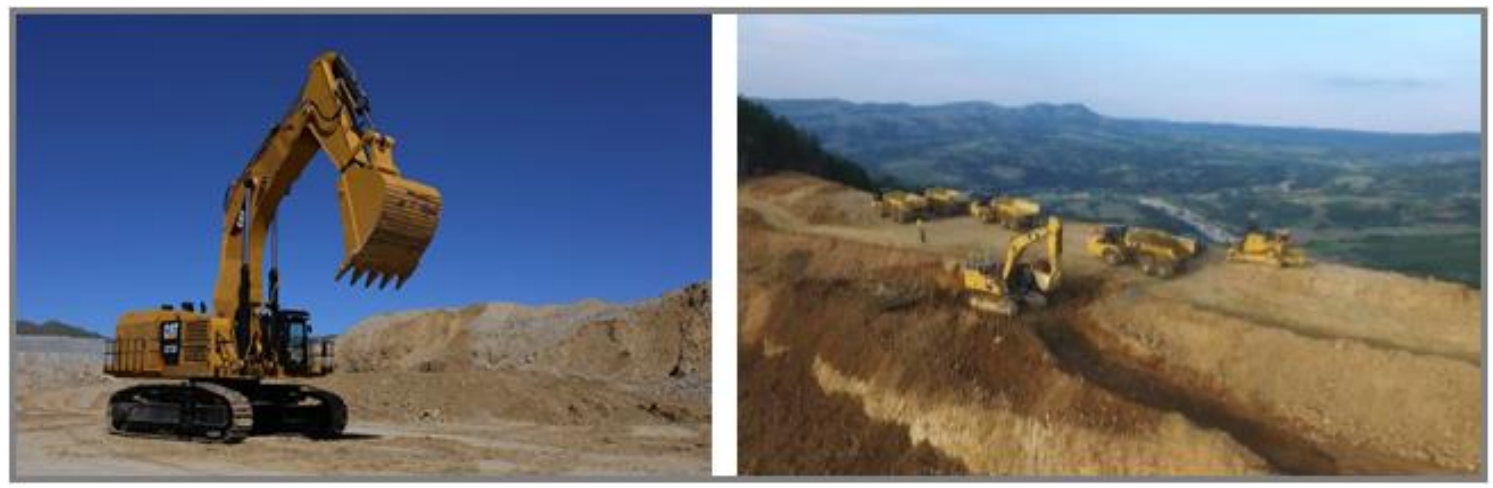

Figure 2. Bucket excavator and haul trucks in "Ada Tepe" gold mine deposit

The ore is processed using physical-chemical techniques to produce a gold ore concentrate that will be transported off-site for further treatment and refinement. Conventional processing methods, including crushing, grinding, and flotation processing are employed for extracting gold at "Ada Tepe" gold mine. The processing plant is anticipated to treat up to 840,000 tonnes per annum (tpa) of ore over the mine life.

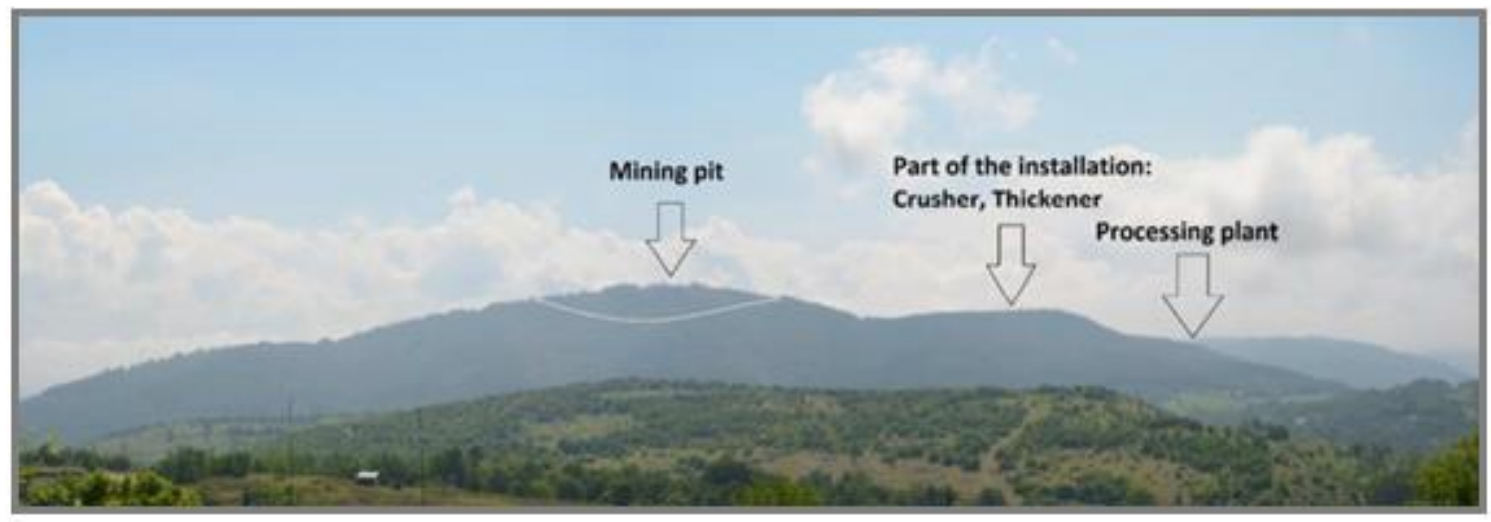

Figure 3. "Ada Tepe" gold mine deposit

Mined ore is delivered to the crushing facility by dumping the material into the run-ofmine (ROM) bin using $50 \mathrm{t}$ dump trucks. A static grizzly is fitted to the top of the ROM bin to remove the oversize (aperture size $600 \mathrm{~mm}$ ) parts of ore. Then this ore is forwarded to a jaw crusher to develop a P100 product of $200 \mathrm{~mm}$ and P80 product of $125 \mathrm{~mm}$. ROM ore is reclaimed from the bin with an apron feeder, which discharges material onto a vibrating grizzly. The primary jaw crusher receives oversize ore from the vibrating grizzly. This ore is crushed to attain a P80 of $110 \mathrm{~mm}$. The primary crusher magnet removes tramp metal before the ore is transported to the coarse ore bin by the coarse ore bin feed conveyor. The coarse ore bin has a live storage capacity of 2520 t. The crushed material is conveyed to the grinding circuit feed conveyor, through two apron feeders [5]. 


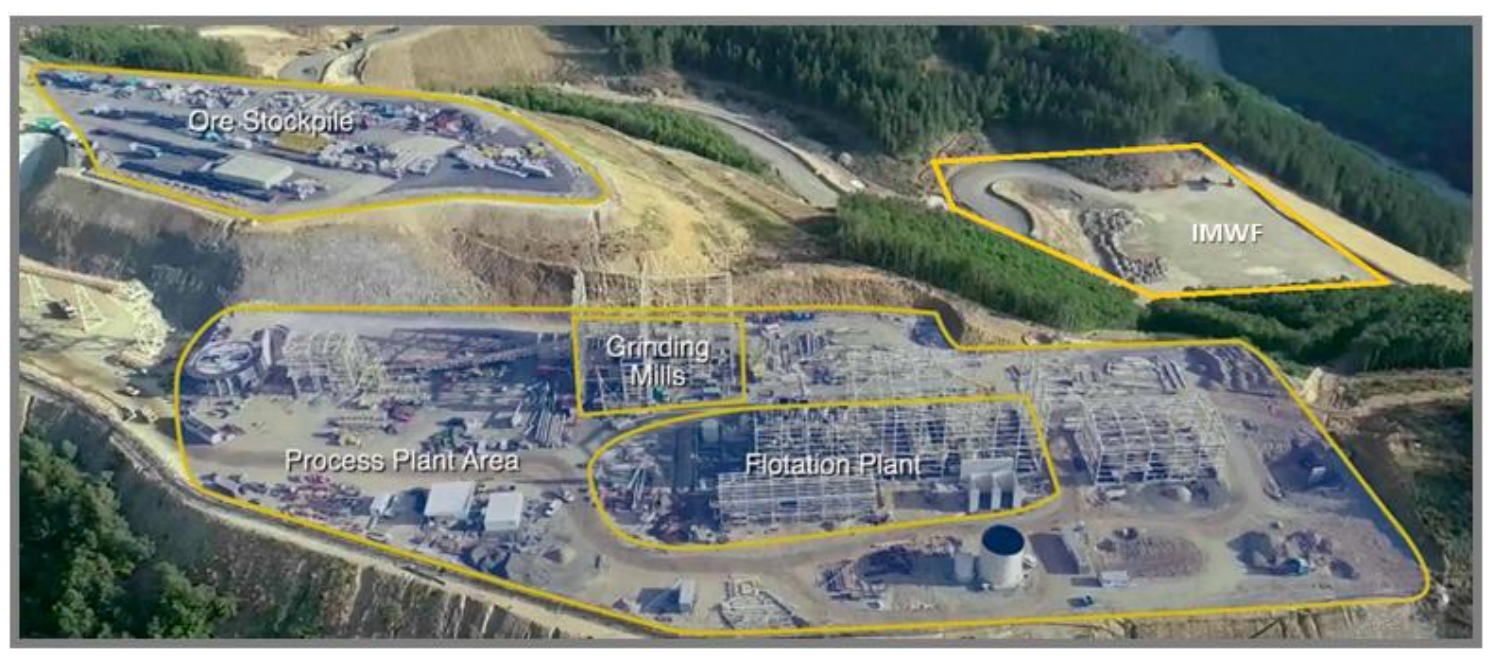

Figure 4. "Ada Tepe" gold mine deposit, process plant area

The grinding circuit comprise a single-stage semi-autogenous grinding (SAG) mill with pebble crushing and a tertiary grinding circuit. The mill operates in closed circuit with the SAG mill cyclone cluster and is designed to grind the coarse ore to a P80 of $125 \mu \mathrm{m}$. The mill discharge slurry is screened via the SAG mill discharge trammel. The SAG mill trammel oversize is transported to the cone type pebble crusher, via two conveyors. Crushed pebbles are discharged from the pebble crusher directly onto a vibrating feeder, from where it discharges onto the SAG mill feed conveyor.

Overflow from the grinding circuit gravitate as feed to the flotation circuit, at the required grind size P80 of 30 microns. The flotation circuit consists of a number of successive steps comprising rougher flotation followed by scavenger flotation, ultra-fine grinding, cleaner flotation step 1, cleaner scavenger flotation and cleaner flotation step 2.

The rougher and scavenger flotation stages consist of four staged flotation reactors configured in series. Each staged flotation reactor (SFR) consists of a particle collection unit (PCU) and a bubble disengagement unit (BDU) fitted with a froth recovery unit (FRU). According to Ivanova et al. [8] this type pneumatic flotation machines have a number of design advantages compared to the conventional pneumo-mechanical flotation machines such as: mixing of solid/liquid and gas phases outside the flotation cell, lack of impeller system, creation of fine air bubbles etc. Furthermore, as reported by Grigorova et al. [9] this type of pneumatic flotation machines, could be applied for processing of various natural and secondary resources such as ultra-fine hydrometallurgical product like zinc cake residue, containing significant amounts of silver, copper and lead. Additionally, a utility model by Nishkov et al. [10] shows that it is possible to use a column pneumatic flotation machine in lead-zinc flotation circuit, in order to improve the grade and recovery of the final lead concentrate.

The feed to rougher flotation comprises the primary regrind mill cyclone overflow, the cleaner/scavenger tailings and the scavenger concentrate, which are collected in the rougher conditioner tank prior to reporting to the rougher flotation bank.

Flotation reagents used in the rougher flotation bank include frother, promoter and collector, with activator (copper sulphate) and dispersant (Sodium silicate) added to the primary regrind mill cyclone underflow launder.

Rougher tailings gravitate to the rougher tails hopper and are pumped via duty pumps to be processed again in the scavenger flotation bank [5]. 
Concentrate from the rougher/scavenger flotation is re-grinded in the tertiary grinding circuit to a P80 size of $15 \mu \mathrm{m}$, and cleaned to produce the final concentrate.

The concentrate is further thickened with a flocculants which aid the settling of particles in the thickener and dewatered in a pressure filter. A filter cake with a moisture content less than $20 \%$ is achieved. The resultant product (final $\mathrm{Au}$ containing concentrate) is packed in sealed containers and shipped [6].

\section{DESCRIPTION OF THE INTEGRATED MINE WASTE FACILITY (IMWF)}

The concept of the IMWF is to place thickened tailings into cells constructed from mine rock. The mine rock provides the strength required for overall stability and also internal drainage. Water drained from these cells is recycled to the processing plant. The IMWF is constructed within two small valleys, being operated as two separate facilities nowadays and later will be merging into a single facility as operations progress. The IMWF is constructed from the bottom up, with mine wastes placed on starting platforms at the bottom of the valley at approximately $300 \mathrm{~m}$ elevation and then progressively is built up in benches during the mine life to elevation $450 \mathrm{~m}$. This allows the lower, completed sections of the facility to be progressively rehabilitated and vegetated during the life of the mining operation [7].

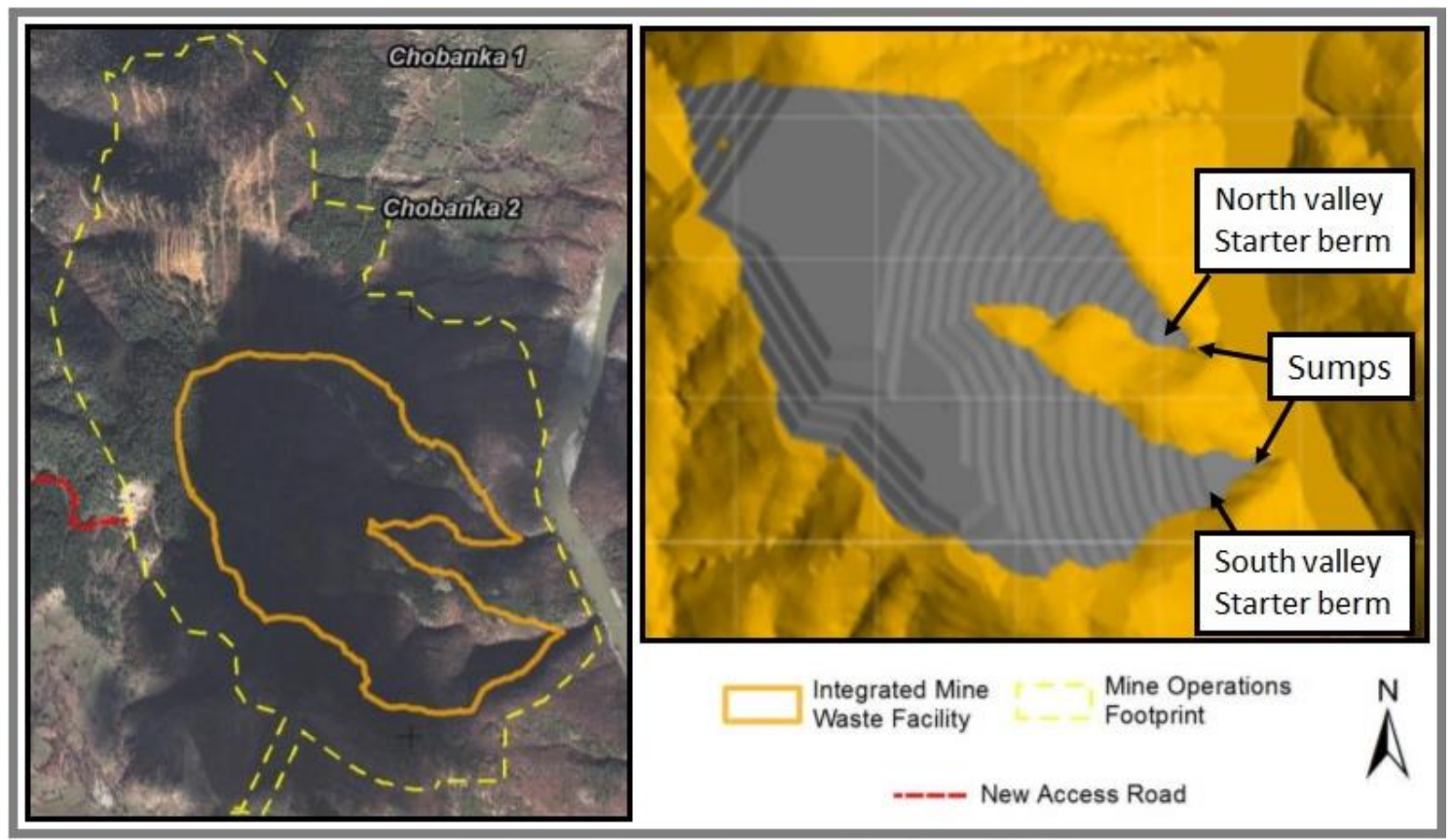

Figure 5. “Ada Tepe” gold mine deposit, integrated mine waste facility (IMWF)

Mine waste and tailings are deposited into two separate catchments (north and south valleys), which eventually join to form a single facility. Water collection sumps are located at the bottom of each valley. 


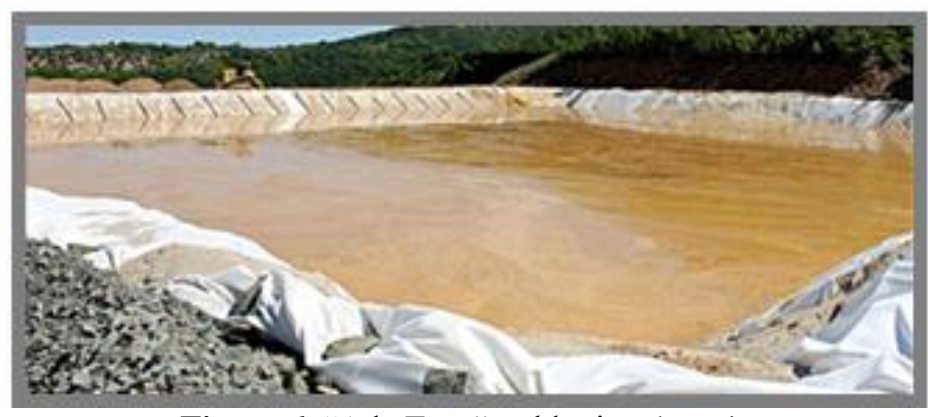

Figure 6. "Ada Tepe" gold mine deposit, integrated mine waste facility (IMWF) - South valley sump

Using IMWF minimises the overall project footprint and also avoids the need for conventional tailings dam because the facility can be progressively rehabilitated while the project is operational. During operations, the external faces of the completed portions of the IMWF can be covered with topsoil and vegetated. This means that the majority of the IMWF can be rehabilitated prior to the end of the mining operations.

\section{CONCLUSION}

The "Ada Tepe" deposit can be classified as a high-grade, shallow, low-sulphidation epithermal style gold-silver deposit. Pit location, size and layout of the ore body are established by prior geological information. Detailed geophysical study was performed to enlighten for main rock types so that makes separation of ore and waste much easier. The entire mineral resource of the "Khan Krum" deposit is found near the surface. Besides how deep the mineral occurrence is located underground, the following factors play a role in the selection of the mining method: surface topography, opportunities for stockpiling the overburden (waste rock or low/poor grade ores lying above), feasible and costeffective transport arrangements, relevant techniques, technology and mining plant and equipment. Therefore, open pit mining and the use of modern environmentally sound methods for mine waste management are considered as suitable mining techniques.

Nowadays mining operations are designed based on solutions that minimised negative environmental impacts from emissions of dust and gas, waste water, solid waste, noise and vibrations on the environmental media, and also in a way that ensure rational use of land.

\section{REFERENCES}

[1]https://www.dundeeprecious.com/English/Operating-Regions/Current-Operations/AdaTepe/Overview/default.aspx , (accessed 17.12.19).

[2] http://www.annualreports.com/HostedData/AnnualReportArchive/d/TSX_DPM_2016.pdf, Annual information form, (accessed 18.12.19).

[3] Blome, M., Maurer, H. and Greenhalgh, S., Geoelectric experimental design - Efficient acquisition and exploitation of complete pole-bipole data sets, Geophysics 76: F15-F26, 2011.

[4] https://s21.q4cdn.com/589145389/files/doc_presentations/2017/Analysts-Visit-April2017_R4_Krumovgrad-technical.pdf, (accessed 02.01.20).

[5] O'Leary, S., Technical specification for technical - mechanical explanatory note for the Krumovgrad gold project № KGP100-2000-1000-RPT-0005, p.6-14, 2016.

[6] https://www.mining-technology.com/projects/krumovgrad-gold-project/, (accessed 17.12.19). 
[7] Anckorn, J., K., Non-Technical Summary Environmental and Social Impact Assessment Krumovgrad Gold Project, Bulgaria, Report № A150-14-R2280, Project № 7879140150, p. 15$18,2014$.

[8] Ivanova, Ts., Grigorova, I., and Ranchev, M., Possibilities for PNEUFLOT flotation machine application in copper-porphyry ore processing plant, Journal of Mining and Geological Sciences, Vol. 62, Num. 2, p. 143-147, 2019.

[9] Grigorova, I., Ivanova Ts., Ranchev, M and Nishkov, I., Pre-contact pneumatic flotation of silver, lead and copper from zinc cake residue, Proceedings of the XVII Balkan Mineral Processing Congress, p. 277-282, 2017.

[10] Nishkov, I., Grigorova, I., Ranchev, M., and Petrov, M., Installation for flotation of lead-zinc ores, BG Utility Model, License № 3243 U1, Patent Office of Republic of Bulgaria, 2019. 